Eurasscience Journals

Eurasian Journal of Forest Science (2017) 5(2): 44-69

\title{
Medicinal plants in ex-situ conservation and its therapeutic in mine impacted lands of dry tropical forests of Jharkhand, India
}

\author{
Raj Shekhar Singh ${ }^{1 *}$, Iqbal Ansari ${ }^{2}$, Ranjeet Kumar Singh ${ }^{2}$, Shailendra Kumar Singh ${ }^{3}$, Debjit $\mathrm{Pal}^{4}$ \\ ${ }^{*}$ Natural Resources \& Environment Management, CSIR-Central Institute of Mining \& Fuel Research, Barwa road, \\ CSIR-CIMFR, Dhanbad Jharkhand, India \\ ${ }^{2}$ AcSIR, CSIR-CIMFR, Dhanbad, Jharkhand, India \\ ${ }^{3}$ CSIR-CIMFR, Dhanbad, Jharkhand, India \\ ${ }^{4}$ Jadavpur University, Kolkata, India \\ Corresponding author: rajcimfr@gmail.com
}

\begin{abstract}
Medicinal plant plays a crucial role in the socio-economic development and maintaining the human health and culture. Naturally, plant-derivative drugs have an imperative position in both traditional and modern medicine. Jharkhand is rich in biodiversity of medicinal plants. The forest area covers about $30.29 \%$ of the total area of Jharkhand. The extensive use of such medicinal plants is nowadays being adopted by almost all the developing and developed countries as therapeutic purpose. It is used to heal various diseases and also prevents the ill effects of synthetic drugs. The main objectives of this article are to identify selected native medicinal properties found in the native forest of Jharkhand and maintain the plants under ex-situ conservation Park for socio-economic development of the tribal which has been used for multipurpose curative applications and their value addition for different diseases. In the current article a total of 41 medicinal plants have been selected for study and documented to their therapeutic use against various types of diseases frequently occurred in tribal dominating mining areas at coal capital of the country located at CSIR-CIMFR, Dhanbad in Jharkhand state of India. disorders.

Keywords: - Ex-Situ conservation, medicinal plants, Terminalia arjuna, epilepsy, Therapeutic use, urinary

Özet

İlaç yapımında kullanılan bitkiler, sosyo-ekonomik gelişme ve insan sağlığının ve kültürünün iyileştirilmesinde çok önemli bir rol oynamaktadır. Doğal olarak, bitkilerden elde edilen ilaçların kullanılması hem geleneksel hem de modern eczacılıkta kaçınılmazdır. Jharkand, tıbbi ilaç yapımında kullanılan bitkiler bakımından yüksek bir bitki çeşitliliğine sahiptir. Ormanlar, Jharkand'ın toplam alanının \%30.29'unu kaplamaktadır. Tedaviye yönelik olarak bu tür bitkilerin ilaç yapımında kullanılması gelişmiş ve gelişmekte olan ülkelerin pek çoğu tarafından benimsenmektedir. Bu bitkilerden yapılan ilaçlar hem çeşitli hastalıkların tedavisinde hem de sentetik ilaçların kullanımından doğan yan etkilerin giderilmesinde kullanılmaktadır. Bu makalenin amacı; Jharkand ormanlarında bulunan ve ilaç yapımında kullanılan önceden belirlenmiş doğal türleri tespit etmek, bu türleri bazı hastalıklara karşı kullanarak değerlendiren aşiretlerin sosyo-ekonomik gelişimine katkıda bulunmak için koruma alanı dışında yetiştirmek ve geliştirmektir. Bu çalışmada, 41 adet doğal tür seçilmiş ve Hindistan'ın Jharkand eyaletine bağlı kömür işletmelerinin en yoğun olduğu Dhanbad şehrinde, bu ilaçları kullanan aşiretler üyelerinin hastalık tedavisinde kullanımlarının dökümü yapılmıştır.
\end{abstract}

Anahtar Kelimeler: Alan-dışı koruma, tıbbi bitkiler, Terminalia arjuna, sara, tıbbi kullanım, üriner sistem rahatsızlıkları. 


\section{Introduction}

Nature has endowed India with rich in medicinal plant resources and its use for medicinal treatments since remote past and the plant-based system continues to be included in a vital responsibility in primary health care of $80 \%$ in terms of world's population (Gupta, 2001). About $25 \%$ of prescribed drugs in the world are originated from plants (Rates, 2001) and more than 3000 species of plants have been reported to have anticancer properties (Graham et. al,). Shahin, et.al, (2008) has reviewed about 24 plants which have their antioxidant properties and are used as vegetables and could be source of dietary antioxidant supplies, which is another emerging area of research.

Products and related drugs obtained from nature are used to treat almost $87 \%$ of all categorized human diseases which includes immunological disorders, bacterial infection, and cancer (Newman and Cragg, 2007). In West African countries still more than $70 \%$ of the people use traditional medicine (Pousset, 1994) and about $80 \%$ of the populations living in developing nations rely on traditional plantbased medicines for their primary health care needs (FAO, 2004).

Globally in China traditional medicine accounts for around $40 \%$ of all health care delivered. About $71 \%$ of the population in Chile and $40 \%$ in Colombia depend on traditional medicines. In India, $65 \%$ of the populations in rural areas use medicinal plants to meet their primary health care needs. In case of developed countries, the percentage of the population that has used such medicines at least once is $48 \%$ in Australia, 31\% in Belgium, $70 \%$ in Canada, $49 \%$ in France and $42 \%$ in the United States of America (WHO, 2003).

There are over 1.5 million practitioners of traditional medicinal system using medicinal plants in preventive, promotional and curative applications. It is estimated that there are over 7800 medicinal drugmanufacturing units in India, which consume about 2000 tons of herbs annually (Verma and Singh 2008). Indians consume plants based as medicinal plants maximum of $20.0 \%$ which is followed by China (18.9 $\%)$, Vietnam (17.1 \%), Sri Lanka (16.5\%) and Thailand (15.5\%). While nations such as the USA, Australia, Indonesia and Malaysia have a high number of plant species, but their utilization as medicinal plants are little. Australia has utilized only $7.8 \%$ of its higher plant flora as medicinal plants and this knowledge remains in Aboriginal communities (Gott, 2008).

India has one of the richest plants medical traditions in the world. Numerous of indigenous species all over the world have through their massive connection with nature collected wide knowledge on medicinal plants and their properties, that's why they are used in treatment of various diseases (Grosvenor et al., 1995; Asase et al., 2010; Maroyi, 2011). There are estimated to be around 25,000 effective plantbased formulations, used in folk medicine and known to rural communities in India.

An herbal medicine is only the platform that provides a basis of treatment and cure for a wide range of diseases and physiological conditions in traditional methods practiced such as Ayurveda, Unani, and Siddha. Several authors has reported that numerous plant species are used by many ethnic groups for the treatment of diverse ailments ranging from minor infections to skin diseases, asthma, malaria, dysentery, and a horde of other indications (Dhar et al., 1968; Perumal and Ignacimuthu, 1998, 2000; Dahanukar et al., 2000).

On the other hand India is one among the other major coal producer and ranked fourth in the world and constitutes 493 coal mines, in which Jharkhand state comprised of 140 mines in 2016. The amount of mine spoil generated during coal mining activities is typically $>2$ to 3 times that of the coal produced itself. Surface mining produced billion tons of spoil annually (Tripathi et. al 2014). Mining spoils possess very harsh conditions for both plant and microbial growth (Singh et al., 2012). Mining operations result in 
severe landscape perturbations that cause major ecosystem damage (Singh et al., 2017) and irreparable impacts to previous soil quality/nutrient cycling capability (Tripathi et al., 2016a). The land use changes drastically change plant species composition and dominant life forms (Tripathi and Singh, 2009, 2012), which in turn affect soils and soil processes (Singh et al., 1991a,Tripathi et al., 2009) and microbial biomass (Singh et al., 1991b, Tripathi and Singh, 2013). Consequently there is great threat of survival of plants due to mining (Tripathi et al., 2016b). The agro-ecology supports production of both agricultural crop, natural medicinal plants and trees (Tripathi et al., 2015). Hence in this paper an attempt has been made to conserve the most frequently used medicinal plant by the local villagers of mining areas and its conservation in ex-situ conservation park at CSIR-CIMFR, Jharkhand, India.

In the world scenario various species of medicinal plants are used by number of countries which has been shown in Table 1.

Table1: Number of Medicinal plant species used by different nations.

\begin{tabular}{cccccc}
\hline $\begin{array}{c}\text { S. } \\
\text { No. }\end{array}$ & Country & $\begin{array}{c}\text { Medicinal Plants } \\
\text { Species }\end{array}$ & $\begin{array}{c}\text { Total No of } \\
\text { Species In Flora }\end{array}$ & $\begin{array}{c}\text { \% of Flora Used as } \\
\text { Medicinal }\end{array}$ & References \\
\hline 1. & India & 7500 & 17000 & 44 & Shiva,1996 \\
2. & China & 11146 & 27100 & 41 & Pei, 2001 \\
3. & North & 2572 & 20000 & 13 & Moerman,1998 \\
& America & & & 7 & Toledo,1995 \\
4. & Mexico & 2237 & 30000 & $10-18$ & Schippmann et al., \\
5. & World & 52885 & $297000-510000$ & & 2002 \\
\hline
\end{tabular}

\section{Materials and Methods}

\section{Study area}

The ex-situ conservation park is located between latitude $23^{\circ} 48^{\prime} 57.20^{\prime \prime} \mathrm{N}$ and longitude $86^{\circ} 25^{\prime}$ 41.71" E at CSIR-CIMFR, Dhanbad, Jharkhand, India. It is strategically situated in the Damodar basin of eastern part of the country which is endowed with rich coal deposits and hosts several large mineral based industries.

Dhanbad district is called Coal Capital of India due to abundance of coal mines operating and one of the most polluted district with respect to air, water and land pollution resulting in spreading of several diseases. Dhanbad has a population of $2,684,487$. Males $(1,405,956)$ constitute $53 \%$ of the population and females $(1,278,531) 47 \%$ (2011 Census Report). It has a sex ratio of 908 . Dhanbad has an average literacy rate of $80.78 \%$, higher than the national average of $74.04 \%$ male literacy is $87.93 \%$ and female literacy is $72.69 \%$.

\section{Climate}

The climate that is dry tropical with a year divisible into three seasons, namely a cold winter (December-February, a very hot summer (April-June) and a rainy season (July-September) (Tripathi et al., 2012).The annual rainfall averages $1,376 \mathrm{~mm}, 80 \%$ of which occurs between late June and September. The mean daily temperature within the annual cycle ranges from 10 to $28^{\circ} \mathrm{C}$, while the mean daily maximum ranges from $26-45^{\circ} \mathrm{C}$ (Singh et al., 1996a). The soil surface layer is $100-110 \mathrm{~mm}$ thick consisting of grey brown to very pale brown sandy load, and clay loam with sub-angular blocky structure. The bedrock is formed of medium to coarse grained sandstone, clay with ferruginous bands and carbonaceous shales. 


\section{Vegetation}

The native typical mixed dry deciduous forest is dominated by tree species Palash (Butea monosperma (Lamb.) Taub), Asan (Terminalia tomentosa Wight \& Arn,) Sal (Shorea robusta Gaertn.) and Shishum (Dalbergia sisoo Rujuta). The species such as Sidha (Lagerstromia parviflora Roxb.), Gamhar (Gmelina arborea Roxb. ex Sm), Siris (Albizzia lebbeck L.Benth), Bahera (Terminalia belerica (Gaertn.) Roxb.), Bel (Aegle marvelous L. Correa) etc. Semal (Bombax malabaricum DC), Khair (Acacia catechu (L.f.) wild), Mahua (Madhuca indica G.F. Gmel), are found scattered in the forests. Salai (Boswellia serrata Roxb. ex Colebr) one of the common species in dry mixed deciduous forests in other parts of Jharkhand is almost absent here except a few poor specimens in Tundi Pahar. Good quality of bamboo forests are found mixed with the miscellaneous forests.

Snakes of the poisonous varieties such as cobra and karait are fairly common and most frequently even Dhaman snake can be seen. In the hilly areas an occasional python is met and various species of harmless grass snakes are generally common in Dhanbad district.

The study was carried through out in planted in the year 2001 at ex-situ conservation Park. The planted specimens were photographed as well as collected, pressed and dried in the field. The species were identified by the Botanical Survey of India, Kolkata The local names of the plants were obtained from the local habitant and documentation. The socio-interaction was carried out to know its therapeutic uses form vaidyas and door to door survey was done. On the basis of this the various therapeutic uses of selected medicinal plants has been identified.

\section{Results}

During the entire study period it was observed that a single plant has been used in curing of various disorders. The list of medicinal plants uses and disorders was compiled and the number of plants used against each category was estimated. The frequency of a single plant used for curing different number of diseases was also calculated as shown in the Table 2.

Table 2: List of Identified Medicinal Plants under Ex-Situ Conservation Park

\begin{tabular}{|c|c|c|c|c|}
\hline S.no & Local name & Botanical Name & Parts used & Medicinal use \\
\hline 1. & Ajwain & $\begin{array}{l}\text { Carum copticum } \\
\text { (L.) C.B.Cl, }\end{array}$ & $\begin{array}{l}\text { Leaves and } \\
\text { Seeds }\end{array}$ & $\begin{array}{l}\text { Reduces flatulence caused by beans when it is } \\
\text { cooked with beans. Seeds used as a substitute for } \\
\text { cumin as well. It is known for supporting the } \\
\text { digestion. }\end{array}$ \\
\hline 2. & Akwan & $\begin{array}{l}\text { Calotropis procera } \\
\text { (Aiton) W.T. Aiton }\end{array}$ & $\begin{array}{l}\text { Roots, stem } \\
\text { bark, latex, } \\
\text { leaves and } \\
\text { flowers }\end{array}$ & $\begin{array}{l}\text { Used in cataract, tooth ache, face marks hair lice and } \\
\text { itching of head. It is used in treatment of epilepsy, } \\
\text { migraine, jaundice, dyspepsia, urinal problems, } \\
\text { eczema, wounds, leprosy and scabies. }\end{array}$ \\
\hline 3. & Arjun & $\begin{array}{l}\text { Terminalia arjuna } \\
\text { (Roxb.) Wight \& } \\
\text { Arn. }\end{array}$ & $\begin{array}{l}\text { Leaves, stem } \\
\text { and bark }\end{array}$ & $\begin{array}{l}\text { Used in menstrual discomfort, as a cardiotonic, } \\
\text { injury, blood disorders, obesity, urinary disorders } \\
\text { and ulcer or wound. Bark powder used as astringent } \\
\text { and diuretic properties. }\end{array}$ \\
\hline 4. & Aswgandha & $\begin{array}{l}\text { Withania somnifera } \\
\text { (L.) Dunal }\end{array}$ & $\begin{array}{l}\text { Seeds, } \\
\text { Stems, } \\
\text { Leaves, } \\
\text { Flowers and } \\
\text { roots }\end{array}$ & $\begin{array}{l}\text { Used as an adaptogen, diuretic, sedative, increases } \\
\text { male and female fertility along with inflammatory } \\
\text { conditions. }\end{array}$ \\
\hline 5. & Bahera & Terminalia bellerica & Fruits, & Used in making hair-oils ailments. It is also the \\
\hline
\end{tabular}


(Gaertn.) Roxb. Kernel, Bark most important constituent of Ayurvedic Triphala. Fruit chewed is believed to cure cough, cold, asthma and hoarse voice.

$\begin{array}{lll}\text { 6. Bel } & \begin{array}{l}\text { Aegle marmelos (L.) } \\ \text { Correa }\end{array} & \begin{array}{l}\text { Leaf, bark } \\ \text { and fruit }\end{array} \\ \text { 7. Biziphus } & \text { jujuba (Miller) } & \begin{array}{l}\text { Fruit pulp } \\ \text { seed, leaves, } \\ \text { Bark and } \\ \text { flowers. } \\ \text { 8. Paan }\end{array} \\ \text { Piper betle }(L .) & \begin{array}{l}\text { Leaves. }\end{array}\end{array}$

9. Brahmi

10. Cactus

11. Chandan

12. Chitrak

13. Dhatura

14. Giloe

15. Gular

16. Gritkumari

17. Imli

18. Jamun

19. Kachnar

20. Kalmegh

21. Karanj
Bacopa monnieri Whole herb (L.) Pennell

Opuntia ficus-indica (L.) Mill

Santalum album L. Wood, oil.

Plumbago zeylanica

L.

Datura stramonium

L.

Tinospora cordifolia (Willd.) Miers

Ficus racemosa $L$.

Aloe vera

Burm.f.

Tamarindus indica Fruits,

L.

Syzygium cumini

(L.) Skeels

Bauhinia variegata

L.

Andrographis

paniculata

(Burm.fil.) Nees

Pongamia pinnata

(L.) Pierre
Fruit and seeds.

Root, root bark and seeds Leaves and seeds

Leaves and stem

Fruits and leaves Seeds, Leaves and Flowers Seed and Pulp

flower bark flower root and

Whole Plant

Fruits, bark, leaf, dried roots, seed oil, and flower.
Leaf, Bark,
Dysentery, stomachache, fistula, piles, hemorrhoids, leucorrhea, mouth ulcers, swelling pimples and nose bleeding.

In diarrhea, dysentery, ulcers, eye infections, vomiting, coughing, and asthma and antifungal effective in poultry suffering from diarrhoea and to humans for indigestion.

Throat, infection, diphtheria, lymphadenopathy, back pain, impotency, erectile dysfunction, indigestion and constipation.

Antioxidant properties. Used as brain tonic, memory enhancer and facilitates learning and used for curing epilepsy and inflammations.

Use as anti-diabetic, anti-inflammatory, analgesic, hypoglycemic, antiviral and anti-oxidant. Preparations have been used to regulate weight, blood sugar, increase fiber intake and facilitate childbirth and are used in the treatment of asthma, fatigue, liver injury.

Chronic bronchitis, gonorrhea and strongly aromatic used in perfume.

Inflammation, bronchitis, itching used in rheumatism and ringworm. Roots used in improving digestion.

Anti-asthmatic agent, asthma, gastric pains and indigestion. It is used in burns, ulcers, sinus infection, headaches, and sores.

Used in rheumatism, gout, dyspepsia, urinary, diseases, liver tonic. Its watery extract is known as Indian quinine.

Anti-diarrhoeal, antidiuretic, antitussive, anti-pyretic and hypoglycemic activities.

Laxative, wound healing, skin burns and care. In ulcer, hydrophobia, dysentery, diabetes and piles.

Used as digestive, carminative, laxative, expectorant antioxidant, anti-inflammatory, antimicrobial, antifungal and anti-viral activity.

In diabetes, anti-allergic, antioxidant, anti-viral, antibacterial, anti cancer, anti inflammation and in gastric ulcer.

In diarrhea, dysentery, malaria, bleeding piles, snakebite, ulcers, tumours, obesity, indigestion, tuberculosis and leprosy.

Immunosuppressive, blood purifier, anthelmintic, astringent. It is used in fever, jaundice, cholera, malaria, anemia, loss of appetite and dysentery.

Oil with citrus lemon fruit juice used in eczema, ring-worm and scabies. 


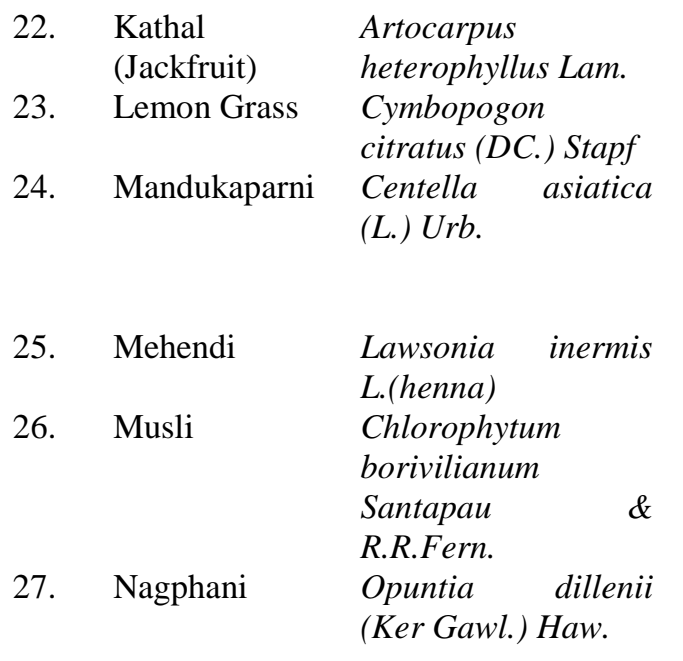

28. Neem

29. Palas

30. Pather Chutt

31. Papita

\section{Azadirachta indica A.Juss.}

Butea monosperma (Lam.) Taub.

Bryophyllum calycinum Salisb.

Carica papaya $L$. seeds fruit Fever, aging, antipyretic anti-asthmatic, and leaves anticancer.

Aerial parts Beneficial in cough and cold, lemon oil is used as aromatic oil and as insect repellent.

Whole plant Antibacterial, anti-inflammatory, in treatment of leprosy and epilepsy. Used for enhancing the receptive capacity of mind in improving the power of speech and poetic imagination.

Leaves, bark Headache, itching and burning sensation, mental and seeds Tuberous roots disorder. Used for cosmetic purposes. or Effective in gonorrhea addition with menorrhagia, prome lower enhancers, dyspepsia aphrodisiac and anti-pyretic properties, vaginal dryness and infertility.

Whole plant Used in treatment of inflammation, constipation and pneumonia.

Rhizome Sedatives, analgesic, epilepsy and hypersensitive.

leaves and

barks

Seeds, gum,

leaves,

flower and

bark

Leaf

Leaves prevent ulcer and treat acute inflammation. It is rich in alkaloids, triterpenes, glyucosides, flavonoids, steroids and lipids.

Fruits, pulp, The juice for warts, corns, cancers of the uterus, seeds and tumors, and thickened skin, syphilis, the tropical roots infection, hemorrhoids, and to remove mineral concretions in the urine; diuretic, to stimulate lactation, labor, or abortion. Ripen fruit used as rheumatism and alkalinizing the urine. Leaves applied externally as an antiseptic or to heal burns or scalds, or to the cervix to contract the uterus.

32. Sissoo

Dalbergia sisoo DC.

Roots, seeds and wood

Oil obtained from the seeds is used to cure skin diseases and leprosy.

Roots

Asparagus
racemosus Willd

34. Sarpagandha

Rauwolfia

serpentina

Benth.ex Kurz

(L.) Fruits and

Leaves,

Improves physical stamina and increases body immunity.

High blood pressure, mental disorders, insomnia, roots

35. Satwan

Alstonia scholaris

Leaves and

(L.) R. Br.

bark

36. Tulsi

Ocimum sanctum Leaves

Var.angustifolium

Benth.

37. Sirish

Albizia lebbeck (L.) Seeds, Benth.

leaves and

roots

Annona squamosa $L$. fruits Roots

Leaves

seeds and

Bark snake bites and hypertension.

Bark decoction in diarrhea and dysentery, milky sap in skin disease.

In cold, cough \& dysentery. It is likely to prove prophylactic against negative effects of environmental toxins and antibacterial properties.

Fungicidal, anti-carcinogenic, immune modulation activities and regulation of cell proliferation. Cholesterol lowering capacity.

In parasitic infections, spinal diseases, a powerful astringent. In Ayurveda used as a good tonic; enriches blood, as expectorant, increases muscular strength, burning sensation, vomiting and destroy 


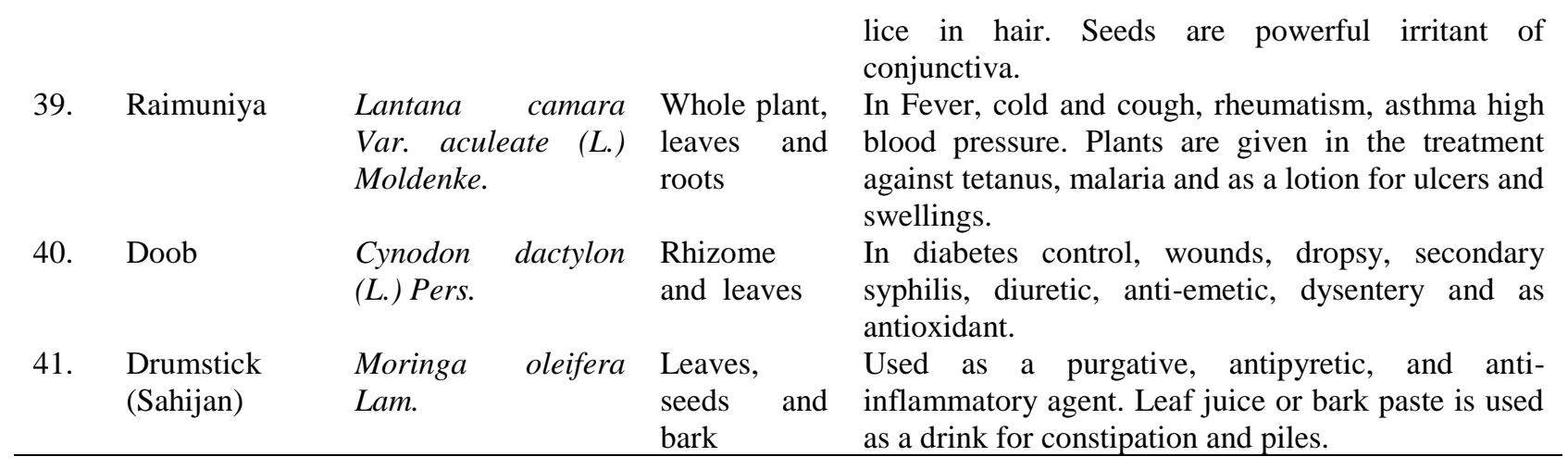

\section{Discussion}

In the term of the richness in traditional knowledge systems related to the use of plant species, India is one of the leading countries in Asia. India is also known for its wealthy diversity of higher plant species (about 17000 species) of which 7500 are known as medicinal plants having its aesthetic value (Shiva, 1996). Our study based on socio-economic survey of village following plants were conserved for day to day use. The result of this study has been described in Table 2 . The described plants has widely distributed in Jharkhand state whose pharmaceutical values are not well documented to be used by the local people.

\section{Ajwain (Carum copticum )}

In the Unani medicinal system basically ajwain is used for enhancing body's resistance (Dymock, 1893) and it is also effective in stomach disorders, amoebiasis and febrile conditions (Basu, 1933). Maryam et. al, 2010 have studied and evaluated the antioxidant and antimutagenic properties from the fruit extract of $C$. copticum. An experimental study reveals that oil of $C$. copticum is extremely effective against Sitophilus oryzae (L.) and Tribolium castaneum (Herbst) beetles and offer a strong insecticidal fumigant for stored product insects (Bibi, 2007).

\section{Akwan (Calotropis procera)}

In India, traditionally the secretion of $C$. procera root bark is used in the treatment of skin diseases, enlargements of abdominal viscera and intestinal worms (Parrotta, 2001).Similarly (Kew, 1985) has studied from the milky latex $C$. procera is useful in the treatment of cutaneous diseases such as ringworm, syphilitic sores and leprosy in Senegal.

\section{Arjun (Terminalia arjuna (Roxb.)}

Terminalia arjuna (Roxb.) is used in the treatment of diverse human diseases such as blood diseases, anemia, venereal and viral disease and to continue excellent healthiness. Beside this it has been also used in the treatment of ulcers, fractures, hepatic and perform, excellent properties of hypocholesterolemic, antibacterial, antimicrobial, anti-tumoral, antioxidant, anti-allergic and antifeedant, anti-fertility and anti-HIV activities (Ram et.al., 1997; Bachaya et.al., 2009; and Phani et.al., 2013).

\section{Aswagandha (Withania somnifera)}

A pilot study have carried out during his clinical investigation they observed that root extract of Withania somnifera performs better in improving sexual function in women(Swati, et al., 2015). A study by Erlandsen et al (2012) focused on the adjuvant therapy against tumor cells, and effects on hypersensitivity and inappropriate immune balance of the Withania somnifera. 


\section{Bahera (Terminalia bellerica)}

A number of authors have reported $T$. bellerica fruits are used in traditional medicine and documented biological activities such as antimicrobial, antidiabetic, anti-oxidant anti-HIV and antiproliferative against cancer cell activities (Elizabeth 2005; Sabu 2009; Kaur 2005 and Valsaraj 1997).

6. Bel (Aegle marmelos)

A study revealed that leaf extracts of Aegle marmelos and its fractions have found fungicidal activity against various clinical isolates of dermatophytic fungi and it drastically inhibits their growth (Balakumar et al 2011).

\section{Ber (Ziziphus jujuba)}

According to Bown 1995; Duke and Ayensu 1985; Him-Che 1985, the dried fruits of Zyzyphus Jujube posses various properties such as an anodyne, anticancer, pectoral, refrigerant, sedative, stomachic, styptic and tonic and immune response enhancer.

\section{Pan (Piper Betle)}

The betel leaves (Piper Betle) are used in a household remedy for the treatment of inflammation in the oral cavity (Satyavati et al 1987). Similarly various authors have also reported for anti-mutagenic, anticarcinogenic, antiplaque, anti-diabetic, anti-inflammatory and antibacterial bioactivities (Amonkar et al., 1986; Padma et al., 1989; Arambewela et al., 2005; Mazura et al., 2007; Nalina and Rahim 2007; Hajare et al., 2011).

\section{Brahmi (Bacopa monniera)}

A study reveals that, the alcoholic extract of Bacopa monniera has provided the ability, consolidation and retention of memory in albino rats and noticed its effect on 3 newly acquired behavioural responses, viz. active conditioned avoidance, Sidman continuous avoidance responses and foot shock motivated brightness discrimination (Singh and Dhawan,1997).

\section{Cactus (Opuntia ficus-indica)}

Various authors have reported from different evidence obtained through an experimental study and it suggested that cactus pear decline cholesterol levels in human blood and also alter low density lipoprotein (LDL) composition (Stintzing and Carle 2005; Stintzing et al., 2001; Gurbachan and Felker 1998; Fernandez et al., 1992 and Frati 1992). In Mexico stems of prickly pear cactus have been traditionally used to treat diabetes (Zou et al. 2005). Several authors have reported from experimental evidences that reduction in cholesterol levels and modification in LDL composition in human blood was found through cactus pear (Ennouri et al. 2006; Frati 992; Gurbachan and Felker 1998).

\section{Chandan (Santalum album)}

Chandan has been considered one of the most holy plant in India and often used to cool the body. George and Ioana 2008 has tested sandalwood oil and found that during Rec assay it showed the properties of anticarcinogenic, antiviral and bactericidal activity. 


\section{Chitrak (Plumbago zeylanica).}

Plumbago zeylanica Linn. is useful in the treatment of impotency (Gogte 2009), leprosy (Kirtikar and Basur 2001), jaundice, migraine, urinary calculi, internal abscesses, insanity, seminal weakness, vaginal discharge (Dev 2006) colic, cough, asthma, helminthiasis, elephantiasis, hepatospleenomagaly, epilepsy, hysteria, nervous and rheumatic affections, obesity, indolent ulcer (Chatterjee and Chandra 2003).

\section{Dhatura (Datura stramonium)}

In the past $D$. stramonium has been used traditionally as an antiasthmatic, an anesthetic, an ointment for burns or rheumatism, and as a psychoactive drug (Hightower 1979). It is used in the treatment of asthma, burns, ulcers, sinus infection, headaches, sores (Mitchell and Ahmad, 2006). It has been observed as a source of alkaloids production and used in both human and veterinary medicine (Kingsbury 1964). It has been also reported for its various pharmacological properties such as an anaesthetic for setting bones, whooping cough, muscle spasm, sciatica, in painful menstruation, treating bruises and wounds, skin ulcers, hemorrhoids, asthma, and for rheumatism. (Satyavati et al., 1976).

\section{Giloe (Tinospora cordifolia)}

The whole, aqueous, standardized extracts of Tinospora cordifolia is used for diabetes, liver tonic and Asparagus racemosus were found to be effective in increasing body immunity and provides protection against a range of biological, physical and chemical stressors (Rege et.al, 1999). It has been also reported that dry barks of $T$. cordifolia posses various pharmacological properties such as has anti-inflammatory (Rai and Gupta, 1966; Pendse et al., 1977), anti-allergic (Nayampalli, 1986), anti-spasmodic, antipyretic (Ikram et al., 1987) and anti-leprotic (Asthana et al., 2001).

\section{Gular (Ficus glomerata)}

The evidence based on the result and it reveals that ethanol extract of $F$. glomerata acts as a powerful antioxidant and a possible radioprotector (Veerapur et.al, 2009). Similarly several co-authors have also reported that the stem bark of $F$. racemosa is robustly effective in anti-diarrhoeal, antidiuretic, antitussive, anti-pyretic and hypoglycemic activities (Mukherijee et.al, 1998; Ratnasooriya et.al, 2003; Bhaskara et.al, 2003; Rao et.al, 2002; and Bhaskara et.al, 2002).

\section{Gritkumari (Aloe vera)}

It has been reported that $A$. vera various pharmacological properties and used in anti-inflammatory, antiarthritis, antibacterial, antifungal, and hypoglycemic effects (Rosca-Casian et al., 2007). Additionally it is also very supportive in controlling against alopecia disease as fungal infections. Similarly Fujita et al (1976) have also reported the anti-microbial and anti-fungal properties of A. Vera. According to Cera et al (1980) the gel of A.Vera is very useful in burning and effective against Pseudomonas seruginosa.

\section{Imli (Tamarindus indica)}

Several researchers have reported the Pharmacological properties of $T$. indica their extracts possess antibacterial, antifungal (Pousset, 1989) properties and also used for cytotoxic (Kobayashi et al., 1996) and gastrointestinal (Coutino-Rodriguez et al., 2001). A 2015 study carried out by Sundaram, m. s. et al demonstrated the anti-arthritic efficiency of tamarind seed extract (TSE). TSE exhibited cartilage and bone protecting nature by inhibiting the elevated activities of MMPs, HAase, exoglycosidases, cathepsins and TRAP. A study reveals that the methanolic leaf extract of $T$. indica shows antibacterial activity against Burkholderia pseudomallei (Muthu et al., 2005). Similar studied was also carried out in which $T$. 
indica have showed imperative antimicrobial activity against Klebsiella pneumonia from methanol and acetone extracts. The antibacterial activity was done by agar disk diffusion method and the activity was compared with standard antimicrobials Amikacin and Piperacillin (Vaghasiya and Chanda 2009).

\section{Jamun (Schizygium cumini)}

It has been reported world widely that the fruit of Syzygium cumini is used for curing various ailments such as cough, diabetes, dysentery, inflammation and ringworm (Reynertson et al, 2005). $S$. cumini is also used by traditional people in the treatment of diabetes, stomachic, and bronchitis (Ruan et al, 2008; Jain et al, 2010).

\section{Kachnar (Bauhinia variegata)}

In India, B. variegata has been broadly used as a medicinal plant in Ayurveda, Unani, Homeopathy and by the ethnic systems of medicines. It is whispered to use as anti-tumour, anti-microbial, antiinflammatory, anti-goitrogenic, hepatoprotective and haemagglutination properties (Mali et al., 2007). The roots of Bauhinia variegata are used as antidote in snake poison (Reddy and Yadava, 2003).

\section{Kalmegh (Andrographis paniculata)}

Several authors have found the ethnopharmacological properties of A. paniculata during in vitro and in vivo studies and illustrate for anti-hepatotoxic, anti-urothelial antihepato- toxic and anti-cold (Caceres et al., 1997; Kapil et al., 1993: Sheeja and Kuttan 2006). In several studies it has also been reported its anti-malarial properties (Najib et.al.1999; Siti et.al., 2002; Dua et.al., 2004; Misra et.al., 1992).

\section{Karanj (Pongamia pinnata)}

During an experimental study the extract derived from the seeds and roots of Pongamia pinnata has reduced pentobarbitone sleeping time, possibly by stimulation of the hepatic microsomal enzyme system (Singh et.al, 1996b). Furthermore from the petroleum ether extract (PEE) of the roots improved pentobarbitone sleeping time, probably due to CNS depression when it was experimented on albino rats (Singh et.al, 1997).

\section{Kathal (Atrocarpus heterophyllus)}

In South- East Asia Artocarpus is used traditionally in the treatment of ulcers, abscess, and diarrhea. It is also used to treat inflammation and malarial fever (Heyne, 1987; Perry, 1980). According to ICUC, 2003 report the extract is used to reduce fever and diarrhea. The roots are also used against skin diseases and asthma (ICUC, 2003).

\section{Lemon grass (Cymbopogon citratus)}

Cymbopogon citratus is used as a sedative in Mexico (Tortoriello and Romero, 1992). The leaves are also consumed as a sedative and analgesic purpose in Brazil (Hiruma- Lima et al., 2002) and Carlini et al. (1986) have found that $C$. citratus is widely used traditionally as medicine for treating nervous disturbances. Similarly the tea prepared from leaves is broadly used as an antiseptic, antifever, antidyspeptic, carminative, tranquilizer and stomachic agent (Barbosa et al., 2008). Several studies reveal that it is also used as anti-inflammatory, antiseptic, diuretic, neurobehavioral, antimicrobial, and fungistatic (Carbajal et al., 1989; Francisco et al., 2011). 


\section{Mandukpurni (Centella asiatica)}

A small herb Centella asiatica is traditionally used in treating skin diseases and leprosy (Chopra et al., 1956) at the same time as it is also showing the wound healing activity (Rosen et al. (1967) and antiulcer activity (Yoshinori et al., 1982). The whole plant of $C$. asiatica is very helpful in improving brain memory (Mukerji, 1953; Vaidyaratnam, 1994).

\section{Mehendi (Lawsonia inermis)}

The study was carried out on memory and behaviour mediated from petroleum ether extract of Lawsonia inermis leaves showed that significant nootropic effect on the elevated plus maze and passive shock avoidance paradigms. The extract also enhanced clonidine induced hypothermia and decreased lithium induced head twitches. Thus it reveals that affects 5HT and noradrenaline mediated behavior and had no effect on haloperidol induced catalepsy, consequently showing no effect on dopamine mediated behavior (Iyer et.al, 1998).

\section{Musli (Chlyorophytum borivilianum)}

The authors investigated pharmacological properties of Chlorophytum borivilianum as carminative, anti-pyretic, diuretic and astringent effects (Kirtikar and Basu, 1975). In addition Chlorophytum borivilianum have also reported for its variety of pharmacological properties such as analgesic (Panda et al., 2007), anti-inflammatory (Panda et al., 2011a), antipyretic (Panda et al., 2011b), hepato protective (Sharma and Kumar, 2011), antimicrobial (Sriram et al., 2012), antioxidant (Kaur et al., 2010), hypolipidemic (Visavadiya and Narasimhacharya, 2011) and antidiabetic (Mujeeb et al., 2009).

\section{Nagphani (Opuntia dillenii)}

The cladodes of $O$. dillenii have been observed for various properties such as antiviral (Ahmad, et al., 1996), antigenotoxic (Zorgui, et al., 2009), anti-inflammatory and wound-healing (Galati et al., 2003). Similarly Loro and Pérez-Santana (1999) have evaluated the analgesic and anti-inflammatory actions of the genus Opuntia from the fruit extract of Opuntia dillenii.

\section{Neem (Azadirchta indica)}

It has been observed that leaves, seeds, roots, bark and the flowers of Azadirachta indica are used for several ailments such as jaundice, stomach ulcers, leprosy, malaria and chicken pox (NRC 2011). Oil from leaves and bark inhibits the growth of pathogenic bacteria especially Mycobacterium and Streptococcus (Biswas et al., 2002).

\section{Palas (Butea monosperma)}

Butea monosperma is usually used in constipation, piles, diabetes, worms, and congested throat (Kapoor 1990). The plant B. monosperma possess a numeral pharmacological properties such as antifungal (Yadava and Tiwari, 2007), antimicrobial (Gurav et al., 2008), antidiabetic (Somani et al., 2006), antihelmintic (Iqbal et al., 2006), anti-inflammatory (Shahavi and Desai, 2008) and antidiarrheal (Gunakkunru et al., 2005). Several researchers have also reported the various therapeutic uses of $B$. monosperma as anti-inflammatory, antioxidative, chemopreventive and hepatoprotective (Sehrawat and Sultana, 2006). 


\section{Pather chutt (Bryophllum pinnatum)}

Recently from in vitro study it was confirmed that $B$. pinnatum inhibits human myometrial contractility it decreases the amplitude of spontaneous contraction while decreasing both the amplitude and frequency of induced contraction (Gwehenberger et al., 2004). A number of pharmacological properties of $B$. pinnatum were observed and used as analgesic in blennorrhoea, syphilis, jaundice, candidiasis, dysmenorrhoea, external ulcers, burns and convulsions. B. pinnatum is also used to treat ear infections, cough and dysentery (Akinpelu, 2000).

\section{Papita (Carica papaya)}

An aqueous and ethanol extracts of Carica papaya has predominately effective in hepatoprotection against carbon tetrachloride induced hepatotoxicity when it was evaluated in rats (Md and Zinnat 2010). According to FAO, (1996) report medicinal plants such as Carica papaya, used in hypertension used in Nigeria.

\section{Sisoo (Delbergia sissoo)}

Several authors have reported that an extract particularly from aerial parts of D. sissoo is used significantly for antipyretic, analgesic, and estrogen-like activities (Sarg et al., 1999). It has also reported its pharmacological properties in stimulation of new cell growth and tissue regeneration (Hajare et al., 2001). Leaf Juice of D. sissoo is very effective in gonorrhoea (Rahman et al., 2008).

\section{Satavar (Asperagus racemosus)}

Basically Asparagus racemosus is used by traditionally for various medicinal properties such as emollient, cooling, nerve tonic, constipating, galactogogue, aphrodisiac, diuretic, rejuvenating, carminative, immunostimulant, gastroprotective and antiseptic effects (Patel and Patel, 2013; Ravishankar et al., 2012; Battu and Kumar, 2010). Several authors has also reported on different pharmacological properties like memory enhancing activity (Ojha et al., 2010), phytoestrogen effects (Sharma et al., 1996), adaptogenic effect (Rege et al., 1999), immunomodulatory effects (Diwanay et al., 2004), antidepressant (Singh et al., 2009; Meena et al. 2011).

\section{Sarpargandha (Roulfia serpentina)}

In India Rauvolfia serpentine is an important medicinal plant. It has been broadly used for centuries in treatment of hypertension, insomnia, anxiety and other disorders of central epilepsy (Ghani, 1998). It has been also reported that it works effectively in mental disease, epilepsy, sleeplessness and numerous other ailments (Ojha and Mishra, 1985). In India and Malaya-peninsula, the root of this plant has been popular from ancient times and used as an antidote especially to insects and poisonous snakes. It is also used as febrifuge and stimulant to uterine contraction for insomnia and mainly for mental illness (Vakil, 1949).

\section{Satwan (Alstonia scholaris)}

Several researchers have reported that A. scholaris possess neuro-pharmacological (Bhattacharya et al., 1979), anticancer (Jagetia and Baliga, 2006), bronchodilatory (Channa et al., 2005), antifertility (Gupta et al., 2005). Khan (2003) reported that the crude methanolic extracts of the leaves, stem and root barks of A. scholaris along with $L$. tetramera have broader spectrum of antibacterial activities. Deena and Thoppil (2000) confirmed that some essential oil of L. camara is very effective against antibacterial and antifungal activities. 


\section{Tulsi (Ocimum sanctum)}

Various researchers have studied the efficiency of Ocimum sanctum essential oil (EO) and its major component, eugenol against the fungi causing biodeterioration of food stuffs during storage. They illustrated that extract obtained from O. sanctum plant in the form EO and eugenol can be a safe preservative against fungal infections (Ashok et al., 2010). In India traditionally use of Ocimum sanctum has recognized for numeral properties such as rejuvenating, tonic, and vitalizing properties that enhances their longevity and a healthy life, and also used for antiseptic, antiallergic, and anticancer (Reen et al., 1996; Samuelsson 1999). According to FAO,(1996) report Ocimum basilicum is used to cure for typhoid fever in Nigeria.

\section{Sirish (Albizia lebbeck)}

Several authors have reported the medicinal importance of $A$. lebbeck to treat snake bites. It is effective in eye-troubles, used as astringent, expectorant and anthelmintic and also effective in piles and diarrohea. Root bark is used for strengthening gums in the form of dental powder (Ch et al., 2006; Sastry and Kavathekar, 1990). A studied has found noticeable inhibitory effect on paw edema shows that $A$. lebbeck possesses a remarkable anti-inflammatory activity to treat various inflammatory diseases (Prakash et. al, 2009). It also provides carbon sequestration benefit (Tripathi et al., 2015).

\section{Sitafal (Annona squamosa)}

During an experimental studied it has been found the potential of nanocrystalline palladium nanoparticles production using acaricidal, insecticidal and larvicidal value of A. squamosa an aqueous peel extract as the biomaterial for the first time. Their results open the possibility of green pathways to produce palladium nanoparticles. A squamosa is broadly used as traditional medicine in different cultures. It is used in the treatment of epilepsy, dysentery, cardiac problem, worm infection, constipation, hemorrhage, antibacterial infection, dysuria, fever, and ulcer. It also possesses the properties such as antifertility, antitumor and abortifacient (Selvaraj et. al., 2012).

\section{Raimuniya/Putus (Lantana camara)}

The study carried by Barreto et. al., (2010) and they found that ethanolic extracts of L. camara leaves and roots exhibited for antimicrobial activity against Staphylococcus aureus, Proteus vulgaris, Pseudomonas aeruginosa, Víbrio cholareae, Escherichia coli and two multi-resistant strains E. coli and $S$. aureus.

\section{Doob (Cynodon dactylon)}

In India $C$. dactylon are usually used in controlling diabetes. Several researchers have also reported the various therapeutic uses of $C$. dactylon for diabetes (Kirtikar and Basu, 1996),diuretic, anti-emetic, purifying agent, in dysentery, as antioxidant and incredibly effective in hypolipidemic (Ahmed et al., 1994; Shivalinge et al., 2009; Sadki et al., 2010; Saroja and Annapoorani 2012; Karthik Ravisankar, 2011; and Rai et al., 2011).

\section{Drumstick (Moringa oleifera)}

It is reported that the seeds of Moringa oleifera is used as a purgative, antipyretic, and antiinflammatory agent (Varier 1997). M. oleifera works as an antioxidant in the presence of high amounts of polyphenols (Fahey, 2005). Several authors have also reported that it is widely used by patients affected from diabetes, hypertension, or HIV/AIDS (Dieye et al., 2008; Kasolo et al., 2010; Monera and Maponga, 2010). In many regions of African country an anti-microbial activity was also found against many 
pathogenic bacteria such as Staphylococcus aureus, Bacillus subtilis, Escherichia coli, and Pseudomonas aeruginosa in dose dependent manner (Saadabi and Abu Zaid, 2011). A clinical study reports that the leaves of M. oleifera considerably decrease blood glucose level in Wistar rats and Goto-Kakizaki (GK) rats, modeled type 2 diabetes (Ndong et al., 2007). Similar study also revealed that the extract of $M$. oleifera leaf is efficient in lowering blood sugar levels within $3 \mathrm{~h}$ after ingestion (Mittal et al., 2007).

According to Farnsworth, et al. (1985) World Health Organization (WHO) has estimated about 4000 million people of the world is dependent on traditional medicine. Additionally medicinal plants are also rich in biologically active compounds and play a vital role in drug discovery. Solanki, (2010), Wandre (2013), Patwardhan et al., (2010) and Shah et al., (2011) reported that the extracts of medicinal plants are used in the treatment of various health problems against bacterial infections, ulcers, arthritis, inflammatory respectively. It has become possible from drugs discovery that medicinal plants have also led to the isolation of cocaine, codeine, digitoxin, and quinine including to morphine drugs and still they are in use (Newman et al., 2000; Butler, 2004; Samuelsson, 2004). An experimental study reveals that ethanolic extracts of aerial parts of Cynodon dactylon (L.) Pers contain anti-diabetic and anti-diarrhoeal properties (Md et al., 2015).

\section{Conclusion}

In terms of importance of such medicinal plants opens the door for researchers in the various fields of pharmacy. More researches are needed to identify the active compound and this will be helpful in determining in proper utilization for personal and for industrial needs. Medicinal plants play an important role in providing knowledge to the researchers in the field of ethno-botany and ethno-pharmacology, so this article will attract the attention of ethno-botanists, phyto-chemists and pharmacologists for further critical investigation of medicinal plants present in Ex-Situ Conservation Park in CSIR-CIMFR, Dhanbad (Jharkhand), India. It has concluded that the above findings of medicinal plants, herbs, and shrubs are the source of diversified flora. Some of the plants were found to have two-fold uses. Further extensive ethnobotanical and ethnopharmacological study may lead to the discovery of bioactive compounds and alkaloids for different diseases. In addition they must be conserved at any cost. Conservation of medicinal plants can be done by extending cultivation of precious and valuable species on the basis of sustainable utilization of biodiversity and carbon sequestration benefits. More emphasis should be given for the implementation in conservation of such valuable medicinal plants.

\section{Acknowledgements}

The authors are grateful to the Director, CSIR-CIMFR Jharkhand, India for their kind permission for publication this article. Authors are also thankful to all staff members of ex situ conservation of Botanical Park without their support and encouragement this work would not have been possible.

\section{References}

Ahmad, A., Davies, J., Randall, S., Skinner, G.R. (1996). Antiviral properties of extract of Opuntia streptacantha. Antiviral Res. 30, 75-85.

Ahmed, S., Reza, M.S., Jabbar, A. (1994). Antimicrobial activity of Cynodon dactylon. Fitoterapia; 65, 463-464.

Akinpelu, D.A. (2000). Antimicrobial activity of Bryophyllum pinnatum leaves. Fitoterapia 71, 193-194.

Amonkar, A.J., Nagabhushan, M., D'Souza, A.V., Bhide, S.V. (1986). Hydroxychavicol: a new phenolic antimutagen from betel leaf. Food Chem Toxicol 24, 1321- 1324.

Arambewela, L.S., Arawwawala, L.D., Ratnasooriya, W.D. (2005). Antidiabetic activities of aqueous and ethanolic extracts of Piper betle leaves in rats. J Ethnopharmacol 102, 239-245. 
Asase, A., Akwetey, G.A., Achel, D.G. (2010). Ethnopharmacological use of herbal remedies for the treatment of malaria in the Dangme West District of Ghana. Journal of Ethnopharmacology 129, 367-376. (Available at: http://www.borneofocus.com/vaic/Statistics/article3.htm).

Ashok, K., Ravindra, S., Priyanka, S., Nawal, K.D. (2010). Chemical composition, antifungal and anti aflatoxigenic activities of Ocimum sanctum L. essential oil and its safety assessment as plant based antimicrobial. Food and Chemical Toxicology 48 (2), 539-543.

Asthana, J.G., Jain, S., Mishra, A., Vijaykanth, M.S. (2001). Evaluation of antileprotic herbal drug combinations and their combination with Dapsone. Indian Drugs 38,82-86.

Bachaya, H.A., Iqbal, Z., Khan, M.N., Jabbar, A., Gilani, A.H., Din I.U. (2009). In vitro and in vivo anthelmintic activity of Terminalia arjuna bark. Int. J. Agric. Biol. 11. 273-278.

Balakumar, S., Rajan, S., Thirunalasundari, T., Jeeva, S. (2011). Antifungal activity of Aegle marmelos (L.) Correa (Rutaceae) leaf extract on dermatophytes. Asian Pac J Trop Biomed 1(4), 309-312.

Barbosa, L.C.A., Pereira, U.A., Martinazzo, A.P., Maltha, C.R.A., Teixeira, R.R., Melo, E.C. (2008). Evaluation of the chemical composition of Brazilian commercial Cymbopogon citratus (D.C.) Stapf samples. Molecules 13, 1864-1874.

Barreto, F.S., Sousa, E.O., Campos, A.R., Costa, J.G.M., Rodrigues, F.F.G. (2010). Antibacterial activity of Lantana camara Linn and Lantana montevidensis Brig extracts from Cariri-Ceará. Brazil. Journal of Young Pharmacists 2 (1), 42-44.

Basu, B.D., Kirtikar, K.R. (1933). Indian Medicinal Plants. Vol.I $2^{\text {nd }}$ ed. Allahabad: Lalit Mohan Basu 1204-1206.

Battu, G.R., Kumar, B.M. (2010). Phytochemical and antimicrobial activity of leaf extract of Asparagus racemosus Willd. Pharmacognosy J. 2, 456-63.

Bhaskara, R.R., Murugesan, T., Pal, M., Saha, B.P., Mandal, S.C. (2003). Antitussive potential of methanol extract of stem bark of Ficus racemosa Linn. Phytother Res. 17, 1117-1118.

Bhaskara, R.R., Murugesan, T., Sinha, S., Saha, B.P., Pal, M., Mandal, S.C. (2002). Glucose lowering efficacy of Ficus racemosa bark extract in normal and alloxan diabetic rats. Phytother Res 16, 590-592.

Bhattacharya, S.K., Bose, R., Dutta, S.C., Ray, A.B., Guha, S.R. (1979). Neuropharmacological studies on strictamine isolated from Alastonia scholaris. Indian J. Exp. Biol. 17, 598-600.

Bibi, Z.S., Saeid, M.P., Mohammad, H.M. (2007). Chemical constituents and fumigant toxicity of essential oil from Carum copticum against two stored product beetles. Insect Science 14, 213-218.

Biswas, K., Chattopadhyay, I., Banerjee, R.K., Bandyopadhyay, U. (2002). Biological activities and medicinal properties of neem (Azadirachta indica). Current Science 82, 1336-45.

Bown, D. (1995). Encyclopaedia of herbs and their uses. Dorling Kindersley, London.

Butler, M.S. (2004). The role of natural product chemistry in drug discovery. Journal of Natural Products 67 (12), $2141-2153$.

Caceres, D.D., Hancke, J.L., Burgos, R.A., Wikman, G.K. (1997). Prevention of common colds with Andrographis paniculata dried extract: A pilot double-blind trial. Phytomedicine 4,101 104.

Carbajal, D., Casaco, A., Arruzazabala, L., Gonzalez, R., Tolon, Z. (1989). Pharmacological study of Cymbopogon citratus leaves. Journal of Ethnopharmacology 25, 103-107. 
Carlini, E.A., Contar, J.D.P., Silva-Filho, A.R., Silveira-Filho, N.G., Frochtengarten, M.L., Bueno, O.F.A. (1986). Pharmacology of lemongrass (Cymbopogon citratus STAPF). I. Effects of teas prepared from the leaves on laboratory animals. Journal of Ethnopharmacology 17, 37-64.

Census of India. Jharkhand district census handbook Dhanbad (2011) series-21 part XII-A (http://www.censusindia.gov.in/2011census/dchb/DCHB_A/20/2009_PART_A_DCHB_DHANBAD.pdf)

Cera, L. Heggers, J., Robson, M., Hagstrom, W. (1980). "The Therapeutic Efficacy of Aloe in Thermal Injuries: Two Case Reports” J. Amer. Animal Hospital Assoc 16, 768-772.

Ch, M.I., Khan, M.A., Hanif, W. (2006). Ethno veterinary medicinal uses of plants from Samahni valley dist. Bhimber, (Azad Kashmir) Pakistan. Asian Journal of Plant Sciences 5(2), 390-396.

Channa, S., Dar, A., Ahmed, S., Atta-ur, Rahman. (2005). Evaluation of Alstonia scholaris leaves for bronchovasodilatory activity. J. Ethnopharmacol 97, 469-476.

Chatterjee, A., Pakrashi, S.C. (2003). The treatise of Indian medical plants (Editors). Vol 4, National institute of science communication and Information Resources, New Delhi, 55- 56.

Chopra, R.N., Nayar, S.L., Chopra, I.C. (1956) Glossary of Indian Medicinal Plants. CSIR, New Delhi 58.

Coutino-Rodriguez, R.P., Cruz, H., Gills-Rios, H. (2001). Lectins in fruits having gastrointestinal activity: their participation in the hem agglutinating property of Escherichia coli 0157: H 7. Archives Med. Res. 32(4), 251259.

Dahanukar, S.A., Kulkarni, R.A., Rege, N.N. (2000). Pharmacology of medicinal plants and natural products. Indian Journal of Pharmacology 32, S81-S118.

Deena, M.J., Thoppil, J.E. (2000). Antimicrobial activity of the essential oil of Lantana camara. Fitoterapia 71 (4), 453-455.

Dev S. (2006). A Selection of prime Ayurvedic plant drugs, Ancient modern concordance, Anamaya publishers, New Delhi, 348- 351.

Dhar, L.M., Dhar, M.M., Dhawan, B.N., Mehrotra, B.N., Ray, C. (1968). Screening of Indian plants for biological activity. Part I. Indian Journal of Experimental Biology 6, 232-247.

Dieye, A.M., Sarr, A., Diop, S.N., Ndiaye, M., Sy, G.Y., Diarra, M., Rajraji Gaffary, I., Ndiaye Sy, A., and Faye, B. (2008). Medicinal plants and the treatment of diabetes in Senegal:survey with patients. Fundam.Clin. Pharmacol. $22,211-216$.

Diwanay, S., Chitre, D., Patwardhan, B. (2004). Immunoprotection by botanical drugs in cancer chemotherapy. J. Ethnopharmacol 90, 49-55.

Dua, V.K., Ojha, V.P., Roy, R., Joshi, B.C., Valecha, N., Usha, D.C., Bhatnagar, M.C., Sharma, V.P., Subbarao, S.K. (2004). Anti-malarial activity of some xanthones isolated from the roots of Andrographis paniculata. J. Ethnopharmacol 95, 247-251.

Duke, J.A., Ayensu, E.S. (1985). Medicinal plants of china. Reference Publications, Institute of Chinese Medicine S219-S224.

Dymock ,W.H. (1893). Pharmacographia Indica. Vol III. Dehra Dun: Bishen Singh p. 116-119.

Elizabeth, K.M. (2005). Antimicrobial activity of Terminalia bellerica. Indian J. Clin. Biochem. 20,150-153. 
Ennouri, M., Fetoui, H., Bourret, E., Zeghal, N., Guermazi, F., Attia, H. (2006). Evaluation of some biological parameters of Opuntia ficus-indica: 2. Influence of seed supplemented diet on rats. Bioresour Technol 97, 21362140 .

Erlandsen, A., Mikolai, J., Murison, A., Mukherjee, S., Zwickey, H. (2012). Invivo immune modulating effects of Ashwagandha (Withania somnifera). BMC Complementary and Alternative Medicine 12(1), P44

Fahey, J.W. (2005). Moringa oleifera: A Review of the Medical Evidence for Its Nutritional, Therapeutic, and Prophylactic Properties. Part 1. Trees for Life J. 1, 1-33.

FAO, (1996). Some medicinal forest plants of Africa and Latin America. Journal of Science 67,75-78, 161-162.

FAO, (2004). Trade in Medicinal Plants Economic and Social Department, Food and Agriculture Organization of the United Nations, Rome, Italy.

Farnsworth, N.R., Akerele, O., Bingel, A.S., Soejarto, D.D., Guo, Z. (1985). Medicinal plants in therapy. Bull World Health Organ 63(6), 965-981.

Fernandez, M.L., Lin, E.C., Trejo, A., McNamara, D.J. (1992). Prickly pear (Opuntia sp.) pectin reverses low density lipoprotein receptor suppression induced by a hypercholesterolemic diet in guinea pigs. J. Nutr. 122, $2330-2340$.

Francisco, V., Figueirinha, A., Neves, B.M., García-Rodríguez, C., Lopes, M.C., Cruz, M.T., Batista, M.T. (2011). Cymbopogon citratus as source of new and safe anti-inflammatory drugs: bio-guided assay using lipopolysaccharide-stimulated macrophages. Journal of Ethnopharmacology 133, 818-827.

Frati, A. (1992). Medical implication of prickly pear cactus. In: Felkar P, Moss LR, editors. Proc. $3^{\text {rd }}$ Annual Texas prickly pear council. 24-25 July. Kingsville, Texas 29-3412(1),44.

Fujita, K., Teradaira, R., Nagatsu, T., Bradykinase (1976). Activity in Aloe Extract. Biochemical Pharmacology 25, 205.

Galati, E.M., Mondello, M.R., Monforte, M.T., Galluzo, M., Miceli, N., Tripodo, M.M. (2003). Effect of Opuntia ficus-indica (L.) Mill. cladodes in wound-healing process. J. Prof. Assoc. Cactus Dev. 5, 1-16.

George, A.B., Ioana, G.C. (2008). Review on safety assessment of sandalwood oil (Santalum album L.). Food and Chemical Toxicology 46(2),421-432.

Ghani, A. (1998). Medicinal plants of Bangladesh. Chemical constituents and uses. Asiatic Society of Bangladesh 36.

Gogte, V.M. (2009). Ayurvedic Pharmacology and therapeutic uses of Medicinal plants (Dravyagunavignyan), translation by the academic team of Bharatiya Vidya Bhavan's SPARC, Chaukhambha Publication, New Delhi 370-372.

Got,t B. (2008). Indigenous use of plants in south-eastern Australia. Telopea 12, 215-26.

Graham, J.G., Quinn, M.L., Fabricant, D.S., Farnsworth, N.R. (2000). Plants used against cancer-an extension of the work of Jonathan Hartwell. Journal of Ethnopharmacology 73(3), 347-377.

Grosvenor, P.W., Gothard, P.K., McWilliam, N.C., Supriono, A., Gray, D.O. (1995). Medicinal plants from Riau Province, Sumatra, Indonesia. Part 1: Uses. Journal of Ethnopharmacology 45,75-95. (http://pib.nic.in/newsite/PrintRelease.aspx?relid=159149, dated on 23'July 2017).

Gunakkunru, A., Padmanaban, K., Thirumal, P., Pritila, J., Parimala, G., Vengatesan, N., Gnanasekar, N., Perianayagam, J.B., Sharma, S.K., Pillai, K.K. (2005). Antidiarrhoeal activity of Butea monosperma in experimental animals. J. Ethnopharmacol 98,241-244. 
Gupta, R.S., Bhatnager, A.K., Joshi, Y.C., Sharma, M.C., Khushalani, V., Kachhawa, J.B. (2005). Induction of antifertility with lupeol acetate in male albino rats. Pharmacology 75, 57-62.

Gupta, S.K. (2001). Pharmacology and Therapeutics in the New Millennium. Narosa Publishing House, New Delhi.

Gurav, S.S, Gulkari, V.D, Duragkar, N.J, Palit, A.T. (2008). Antimicrobial activity of Butea monosperma Lam. Gum. Iran J Pharm Ther 7,21-24.

Gurbachan, S., Felker, P. (1998). Cactus: new world foods. Indian Horticulture 43, 29-31.

Gwehenberger, B., Rist, L., Huch, R., von Mandach, U. (2004). Effect of Bryophyllum pinnatum versus fenoterol on uterine contractility. Eur. J. Obstet. Gynecol. Reprod Biol. 113, 164-71.

Hajare, S.W., Chandra, S., Sharma, J., Tandan, S.K., Lal, J., Telang, A.G. (2001). Anti-inflammatory activity of Dalbergia sissoo leaves. Fitoterapia 72,131-139.

Hajare, R., Darvhekar, V.M , Shewale, A., Vijay, P.V. (2011) Evaluation of antihistaminic activity of Piper betel leaf in guinea pig. African Journal of Pharmacy and Pharmacology 5(2), 113-117

Heyne, K. (1987). The Useful Indonesian Plants. Research and Development Agency. The Ministry of Forestry, Jakarta 659-703.

Hightower, C.E. (1979). Plants that kill and cure. Vet. Human Toxicol. 21, 360-362.

Him-Che, Y. (1985). Handbook of Chinese herbs and formulas. Institute of Chinese Medicine S219-S224.

Hiruma-Lima, C.A., Guimarães, E.M., Santos, C.M., Di Stasi, L.C. (2002). Commelinidae medicinais. In: Di Stasi LC, Hiruma-Lima, CA (Eds.). Plantas Medicinais na Amazônia e na Mata Atlântica. Editora UNESP, São Paulo $41-50$.

ICUC, (2003). International Centre for Underutilized Crops Report, Department of Civil and Environmental Engineering, University of Southhampton, SO 17 1BJ, UK.

Ikram, M., Khattak, S.G., Gilani, S.N. (1987). Antipyretic studies on some indigenous Pakistani medicinal plants: II. J. Ethnopharmacol. 19,185-192.

Iqbal, Z., Lateef, M., Jabbar, A., Ghayur, M.N., Gilani, A.H. (2006). In vivo anthelmintic activity of Butea monosperma against trichostrongylid nematodes in sheep. Fitoterapia 77,137-140.

Iyer MR, Pal SC, Kasture VS, Kasture SB. (1998). Effect of Lawsonia inermis on memory and behaviour mediated via monoamine neurotransmitters. Indian J Pharmacol 30:181-185.

Jagetia, G.C., Baliga, M.S. (2006). Evaluation of anticancer activity of the alkaloid fraction of Alstonia scholaris (Sapthaparna) in vitro and in vivo. Phytother Res 20, 103-109.

Jain, A., Sharma, S., Goyal, M., Dubey, S., Jain, S., Sahu, J., Sharma, A., Kaushik, A. (2010). Anti-inflammatory activity of Syzygium cumini leaves. Int J Phytomed 2,5124-126.

Kapil, A., Koul, I.B., Banerjee, S.K., Gupta, B.D. (1993). Antihepatotoxic effects of major diterpenoid constituents of Andrographis paniculata. Biochem Pharmacol 46,182-185.

Kapoor, L.D. (1990). Butea monosperma. CRC handbook of Ayurvedic medicinal plants. Boca Raton: CRC Press; 86.

Karthik, D., Ravikumar, R. (2011). Proteome and phytochemical analysis of Cynodon dactylon leaves extract and its biological activity in diabetic rats. Biomed. Prev. Nutr. 1(1), 49-56. 
Kasolo, J.N., Bimenya, G.S., Ojok, L., Ochleng, J., Ogwal, O.J.W. (2010). Phyochemicalsandusesof Moringa oleifera leaves in Ugandan rural communities. J.Med.PlantRes. 4, 753-757.

Kaur, R., Thukra, A.K., Arora, S. (2010). Attenuation of free radicals by an aqueous extract of peels of safed musli tubers (Chlorophytum borivilianum Santet Fernand). Journal of Chinese Clinical Medicine 5, 7-11.

Kaur, S., Michael, H., Arora, S., Harkonen, P.L., Kumar, S. (2005). The in vitro cytotoxic and apoptotic activity of Triphala an Indian herbal drug. J. Ethnopharmacol. 97, 15-20.

Kew, F. (1985). The useful plants of West Tropical Africa, Families A - D Edition 2 (ed Burkill, H. M. Royal Botanical Gardens 1, 219-222.

Khan, M.R. Omoloso, A.D, Kihara, M. (2003). Antibacterial activity of Alstonia scholaris and Leea tetramera. Fitoterapia 74, 736-740.

Kingsbury, J.M. (1964). Poisonous plants of the United States and Canada. Prentice Hall. Inc. New Jersey p 626.

Kirtikar, K.R., Basu, B.D., CS, I. (2001). Indian Medicinal Plants, Second Edition Oriental Enterprises, Dehradun, 6, 2029-2035.

Kirtikar, K.R., Basu, B.D. (1996). Indian Medicinal Plants, 2nd Edn, Allahabad, India, International book distributor $4,1020$.

Kirtikar, K.R., Basu, B.D. (1975). Liliaceae: Chlorophytum. In: Kirtikar, K.R., Basu, D. (Eds.), Indian Medicinal Plants. L.M. Basu, Publishers, Allahabad 2508-2509.

Kobayashi, A., Adenan, M.L., Kajiyama, S.I., Kanzaki, H., Kawazu, K. (1996). A cytotoxic principle of Tamarindus indica, di-n-butyl malate and the structure-activity relationship of its analogues. Journal of Biosciences, 51 , (34), 233-242.

Loro, J.F., del Rio, I., Pérez-Santana, L. (1999). Preliminary studies of analgesic and anti-inflammatory properties of Opuntia dillenii aqueous extract. J. Ethnopharmacol. 67, 213-218.

Mali, R.G.; Mahajan, S.G. Mehta, A.A. (2007). Rakta kanchan (Bauhinia variegata): Chemistry, traditional and medicinal uses - a review. Pharmacognosy Reviews, 1(2), 314-319.

Maroyi, A. (2011). An ethnobotanical survey of medicinal plants used by the people in Nhema communal area, Zimbabwe. Journal of Ethnopharmacology 11,347-354.

Maryam, Z., Iqbal, A., Farrukh, A. (2010). Antioxidant and antimutagenic activity of Carum copticum fruit extracts. Toxicology in Vitro 24,1243-1249.

Mazura, M.P., Nuziah, H., Rasadah, M.A., Ling, S.K. (2007). Evaluation of Piper betle on platelet activating factor (PAF) receptor binding activities. MJS 26, 79-83.

Md, S.R., Rasheda, A., Santosh, M., Faridul, I., Nusrat, J.M., Nemai, C.N., Abu Sayeed, M.M. (2015). Antidiabetic and antidiarrhoeal potentials of ethanolic extracts of aerial parts of Cynodon dactylon Pers. Asian Pac. J. Trop. Biomed. 5(8), 658-662.

Md, Z.S., Zinnat, A.B. (2010). Protective effect of dried fruits of Carica papaya on hepatotoxicity in rat. Bangladesh J. Pharmacol. 5, 48-50.

Meena, J., Ojha, R., Muruganandam, A.V., Krishnamurthy, S. (2011). Asparagus racemosus competitively inhibits in vitro the acetylcholine and monoamine metabolizing enzymes. Neurosci Lett 503, 6-9. 
Misra, P., Pal, N.L., Guru, P.Y., Katiyar, J.C., Srivastava, V., Tandon, J.S. (1992). Antimalarial activity of Andrographis paniculata (Kalmegh) against Plasmodium berghei NK 65 in Mastomys natalensis. Int J Pharmacog 30,263-274.

Mitchell, S.A., Ahmad, M.H. (2006). A Review of Medicinal Plant Research at the University of the West Indies, Jamaica. West Indian Med, J. 55 (4), 243.

Mittal, M., Mittal, P., Agarwal, A.C. (2007). Pharmacognostical and phytochemical investigation of antidiabetic activity of Moringa oleifera lam leaf. Ind. Pharm. 6,70-72.

Moerman, D.E. (1998). Native North American food and medicinal plants: epistemological considerations. In: Prendergast H.D.V., Etkin, N.L., Harris, D.R., Houghton, P.J. (eds) Plants for Food and Medicine. Proceedings from a Joint Conference of the Society for Economic Botany and the International Society for Ethnopharmacology, London, 1-6 July. Royal Botanic Gardens, Kew, UK 69-74.

Monera, T.G., Maponga, C.C. (2010). Moringa oleifera supplemen-tation by patients on antiretroviral therapy. J. Int. AIDS Soc. 13, 188.

Mujeeb, M., Khan, S.A., Ali, M., Mall, A., Ahmad, A. (2009). Antidiabetic activity of the aqueous extract of Chlorophytum borivilianum L. in Streptozotocin induced hyperglycemic rats-a preliminary study. Journal of Pharmacy Research 2, 5-53.

Mukerji, B. (1953). Indian pharmaceutical codex, Council of Scientific and Industrial Research, New Delhi, India 1953, 60- 1 .

Mukherijee, P.K., Saha, K., Murugesan, T., Mandal, S.C., Pal, M., Saha, B.P. (1998). Screening of anti-diarrhoeal profile of some plant extracts of a specific region of West Bengal, India. J Ethnopharmacol 60,85-89.

Muthu, S.E., Nandakumar, S., Roa, U.A. (2005). The effect of methanolic extract of Tamarindus indica on the growth of clinical isolates of Burkholderia pseudomallei. Indian J. Med. Res. 122,525-8.

Najib, N.A., Furuta, T., Kojima, S., Takane, K., Ali Mohd, M. (1999). Antimalarial activity of extracts of Malayasian medicinal plants. J. Ethnopharmacol. 64,249-254.

Nalina, T., Rahim, Z. (1992). The National Research Council (US). Board on Science and Technology for International Development. Neem: a tree for solving global problems. National Academy Press. Washington, DC

Nayampalli, S.S., Desai, N.K., Ainapure, S.S. (1986). Anti-allergic properties of Tinospora cardifolia in animal models. IndianJ Pharm 18,250-252.

Ndong, M., Uehara, M., Katsumata, S., Suzuki, K. (2007). Effects of oral administration of Moringa oleifera Lam on glucose tolerance in gotokakizaki and wistar rats. J. Clin. Biochem. Nutr. 40,229-233.

Newman, D.J., Cragg, G.M., Snader, K.M. (2000). The influence of natural products upon drug discovery. Natural Product Reports 17 (3), 215 - 234.

Newman, D.J., Cragg, G.M. (2007). Natural products as sources of new drugs over the last 25 years. Journal of Natural Products 70(3), 461-477.

NRC, (2011). Azadirachta indica as a public health tool for the control of malaria \& other vector-borne diseases. (https://www.thefreelibrary.com/Azadirachta+indica+as+a+public+ health+tool +for+ the+control +of +malaria... $-\mathrm{a} 0221760988)$

Ojha, J., Mishra, U. (1985). Dhanvantari Nighantuh, with hindi translation and commentary, Ist ed. Dept. of Dravyaguna, Institute of Medical Sciences, BHU, Varanasi p. 204. 
Ojha, R., Sahu, A.N., Muruganandam, A.V., Singh, G.K., Krishnamurthy, S. (2010). Asparagus recemosus enhances memory and protects against amnesia in rodent models. Brain Cogn 74, 1-9.

Padma, P.R., Lalitha, V.S., Amonkar, A.J., Bhide, S.V. (1989). Anticarcinogenic effect of betel leaf extract against tobacco carcinogens. Cancer Lett. 45, 195-202.

Panda, S.K., Das, D., Tripathy, N.K. (2011a) Anti-inflammatory potential of Chlorophytum borivilianum Sant and Fern. root tubers. Journal of Global Trends in Pharmaceutical Sciences 2,242-251.

Panda, S.K., Das, D., Tripathy, N.K. (2011b) A study on antipyretic activity of Chlorophytum borivilianum Sant and Fern. root tubers. International Journal of Pharmaceutical Research and Development 3, 153-156.

Panda, S.K., Si, S.C., Bhatnagar, S.P. (2007). Studies on hypoglycaemic and analgesic activities of Chlorophytum borivilianum Sant and Ferz. Journal of Natural Remedies 7, 31-36.

Parrotta, J.A. (2001). Healing plants of peninsular India. AB International Wallingford UK 944.

Patel, L.S., Patel, R.S. Antimicrobial Activity of Asparagus racemesus Wild from Leaf Extracts. Int J Sci. Res. Pub. 3, 1-3.

Patwardhan, S., Bodas, K.S., Gundewar, S. (2010). Coping with arthritis using safer herbal options. Int. J. Pharm. Pharmcol. Sci 2(1),1-11.

Pei, S. (2001). Ethnobotanical approaches of traditional medicine studies: some experiences from Asia. Pharmaceutical Botany 39,74-79.

Pendse, V.K., Dadhich, A.P., Mathur, P.N., Bal, M.S., Madam, B.R. (1977). Anti-inflammatory, immunosuppressive and some related pharmacological actions of the water extract of Neem Giloe (Tinospora cordifolia)-A preliminary report. Indian J. Pharm. 9, 221-224.

Perry, L.M. (1980). Medicinal Plants of East and South East Asia Attributed Properties and Uses. MIT Press, Cambridge.

Perumal, S.R., Ignacimuthu, S. (2000). Antibacterial activity of some folklore medicinal plants used by tribals in Western Ghats of India. Journal of Ethnopharmacology 69, 63-71.

Perumal, S.R., Ignacimuthu, S. (1998). Screening of 34 Indian medicinal plants for antibacterial properties. Journal of Ethnopharmacology 62,173-178.

Phani, Kumar G., Navya, K., Ramya, E.M., Venkataramana, M., Anand, T., Anilakumar, K.R. (2013). DNA damage protecting and free radical scavenging properties of Terminalia arjuna bark in PC-12 cells and plasmid DNA. Free Radic Antioxid 3, 35-39.

Pousset, J.L. (1989). Plantes médicinales africaine, Utilisations Pratiques. Ellipses (Ed.), Paris, p. 95.

Pousset, J.L. (1994). Plantes médicinales africaines. Le Pharmacien d'Afrique 87, 16.

Prakash, B.N., Pandi kumar, P, Ignacimuthu, S. (2009). Anti-inflammatory activity of Albizia lebbeck Benth an ethnomedicinal plant, in acute and chronic animal models of inflammation. Journal of Ethnopharmacology 125, 356-360.

Rahman, A.H.M.M., Anisuzzaman, M., Haider, S.A., Ahmed, F., Islam, A.K.M.R., Naderuzzama, A.T.M. (2008). Study of medicinal plants in the Graveyards of Rajshahi city. Research Journal of Agriculture and Biological Sciences 4(1), 70-74. 
Rai, D.K., Sharma, R.K., Rai, P.K., Watal, G., Sharma, B. (2011). Role of aqueous extract of Cynodon dactylon in prevention of carbofuran induced oxidative stress and acetyl cholinesterase inhibition in rat brain. Cell. Mol. Biol. 57, 135-142.

Rai, M., Gupta, S.S. (1966). The deposition of the secondary salts over the five pellets in rats was inhibited by the aqueous extract of T. cordifolia. J. Res. Ind. Med. 10,113-116.

Ram, A., Lauria, P., Gupta, R., Kumar, P., Sharma, V.N. (1997). Hypocholesterolaemic effects of Terminalia arjuna tree bark. J. Ethnopharmacol. 55, 165-169.

Rao, R.B., Anupama, K., Swaroop, K.R., Murugesan, T., Pal, M., Mandal, S.C. (2002). Evaluation of anti-pyretic potential of Ficus racemosa bark. Phytomedicine 9, 731-733.

Rates, S.M.K. (2001). Plants as source of drugs. Toxicon. 39(5), 603-613.

Ratnasooriya, W.D., Jayakody, J.R., Nadarajah, T. (2003). Antidiuretic activity of aqueous bark extract of Sri Lankan Ficus racemosa in rats. Acta. Biol. Hung. 54, 357-363.

Ravishankar, K., Kiranmayi, G.V.N., Lalitha, T.M., Priyanka, T., Ranjith, T., Someswarao, S.B.V., Raju, V.R.K., Divya, A.V. (2012). Preliminary phytochemical screening and in vitro antibacterial activity on Asparagus racemosus root extract. Int. J. Pharm. Chem. Biol. Sci. 2,117-23.

Reddy, V.M.S., Yadava, R.N. (2003). Anti-infl ammatory activity of a novel flavonol glycoside from the Bauhinia variegata Linn. Nat. Prod. Res. 17, $165-169$.

Reen, R.K., Roesch, S.F., Keifer, F., Wiebel, F.J., Singh, J. (1996). Piperine impairs cytochrome P4501A1 activity by direct interaction with the enzyme and not by down regulation of CYP1A1 gene expression in the rat hepatoma 5L cell line. Biochem. Biophys. Res. Commun. 218,562-569.

Rege, N.N., Thatte, U.M., Dahanukar, S.A. (1999). Adaptogenic properties of six rasayana herbs used in Ayurvedic medicine. Phytother Res. 13, 275-91.

Reynertson, K.A., Basile, M.J., Kennelly, E.J. (2005). Antioxidant potential of seven myrtaceous fruits. Ethnobot. Res. Appl. 3,25-35.

Rosca-Casian, O., Parvu, M., Vlase, L., Tamas, M. (2007). “Antifungal activity of Aloe vera leaves," Fitoterapia 78(3),219-222.

Rosen, H., Blumenthal, A., McCallum, J. (1967). Effect of asiaticoside on wound healing in rats. Experimental Medicine and Surgery 125, 279-280.

Ruan, P.Z., Zhang, L.L., Lin, M.Y. (2008). Evaluation of the antioxidant activity of Syzygium cumini leaves. Mole $13,2545-2556$.

Saadabi, A.M., Abu, Zaid (2011). An in vitro antimicrobial activity of Moringa oleifera L. seed extracts against different groups of microorganisms. Asian J. Basic Appl. Sci. 5,129-134.

Sabu, M.C., Kuttan, R. (2009). Antidiabetic and antioxidant activity of Terminalia belerica Roxb. Indian J. Exp. Biol. 47, 270- 275.

Sadki, C., Hacht, B., Souliman, A., Atmani, F. (2010). Acute diuretic activity of aqueous Erica multiflora flowers and Cynodon dactylon rhizomes extracts in rats. J. Ethnopharmacol. 128,352-356.

Samuelsson, G. (1999). Drugs of Natural Origin: A Textbook of Pharmacognosy; Swedish Pharmaceutical Press: Stockholm, Sweden. 
Samuelsson, G. (2004). Drugs of Natural Origin: a Textbook of Pharmacognosy, 5th Swedish Pharmaceutical Press, Stockholm.

Sarg, T., Ateya, A.M., Afaf, A.G., Badr, W., Shams, G. (1999). Phytochemical and pharmacological studies of Dalbergia sissoo growing in Egypt. Pharmaceut. Biol. 37(1), 54-62.

Saroja, M., Annapoorani, S. (2012). Antitumor activity of methanolic extract of Cynodon dactylon leaves against Ehrlich ascites induced carcinoma in mice. J. Adv. Sci. Res. 3(1),105-108.

Sastry, C.S., Kavathekar, K.Y. (1990). Plants for Reclamation of wastelands. (Eds). Publications and Information Directorate, CSIR, New Delhi. 95-96.

Satyavati, G.V., Raina, M.K., Sharma, M. (1987). Medicinal Plants of India. New Delhi: Indian Council of Medical Research, New Delhi, India

Satyavati, G.V., Rama, M.K., Sharma, M. (1976). Medicinal Plants of India, ICMR, vol. 1, New Delhi 333-334.

Schippmann, U., Leaman, D.J., Cunningham, A.B. (2002). Impact of Cultivation and Gathering of Medicinal Plants on Biodiversity: Global Trends and Issues. Inter-Department Working Group on Biology Diversity for Food and Agriculture, FAO, Rome, Italy.

Sehrawat, A., Sultana, S. (2006). Chemoprevention by Butea monosperma of hepatic carcinogenesis and oxidative damage in male Wistar rats. Asian Pacific Journal of Cancer Prevention 7, 140-148.

Selvaraj, M.R., Annadurai, B., Rajendran, K., Venkatesh, G.K., Arunachalam, P. (2012). Acaricidal, insecticidal, and larvicidal efficacy of aqueous extract of Annona squamosa L peel as biomaterial for the reduction of palladium salts into nanoparticles. Colloids and Surfaces B: Biointerfaces. 92,209-212.

Shah, B.N., Seth, A.K., Maheshwari, K.M. (2011). A review on medicinal plants as sources of anti-inflammatory agents. Res. J. Med. Plant 5,101-115.

Shahavi, V.M., Desai, S.K. (2008). Anti-inflammatory activity of Butea monosperma flowers. Fitoterapia 79,82-85.

Shahin, S.A., Naresh, K., Abhinav, L., Angad, S., Hallihosur, S., Abhishek, S., Utpal, B. (2008). Review on Indian medicinal herbs as sources of antioxidants. Food Research International 41, 1-15.

Sharma, S., Ramji, S., Kumari, S., Bapna, J.S. (1996). Randomized controlled trial of Asparagus racemosus (shatavari) as lactagogue in lactational inadequacy. Indian Paediatr. 33,675-77.

Sharma, S.K., Kumar, M., (2011). Hepatoprotective effect of Chlorophytum borivilianum root extract against arsenic intoxication. Pharmacology online 3,1021-1032.

Sheeja, K., Kuttan, G. (2006). Protective effect of Andrographis paniculata and andrographolide on cyclophosphamide-induced urothelial toxicity. Int. Cancer Therapy 5,244-251.

Shiva, V. (1996). Protecting our Biological and Intellectual Heritage in the Age of Biopiracy. The Research Foundation for Science, Technology and Natural Resources Policy, New Delhi, India.

Shivalinge, G.K.P., Satish, S., Mahesh, C.M., Vijay, K. (2009). Study on the diuretic activity of Cynodon dactylon root stalk extract in Albino rats. Res. J. Pharm. Tech. 2(2),338-340.

Singh, G.K., Garabadu, D., Muruganandam, A.V. (2009). Antidepressant activity of Asparagus racemosus in rodent models. Pharmacol. Biochem. Behav. 91,283-90.

Singh. H.K., Dhawan, B.N. (1997). Neuropsycho-pharmacological effects of the ayurvedic nootropic Bacopa monniera Linn. (Brahmi) Indian J. Pharmacol. 29,S359-65. 
Singh, R.K., Joshi, V.K., Goel, R.K., et al. (1996b). Pharmacological actions of Pongamia pinnata seeds - a preliminary study. Indian J. Exp. Biol. 34,1204-1207.

Singh, R.K., Nath, G., Acharya, S.B., et al. (1997). Pharmacological actions of Pongamia pinnata roots in albino rats. Indian J. Exp. Biol. 35,831-836.

Singh, R.S., Raghubanshi, A.S., Singh, J.S. (1991). Nitrogen mineralization in dry in dry tropical savanna: effects of burning and grazing. Soil Biology and Biochemistry (Great Britain), 23,269-273.

Singh, R.S., Srivastava, S.C., Raghubanshi, A.S., Singh, J.S., Singh, S.P. (1991). Microbial C, N and P in dry tropical savanna: Effects of burning and grazing. Journal of Applied Ecology (UK). 28,869-878.

Singh, R.S., Chaulya, S.K., Tewary, B.K., Dhar, B.B. (1996). Restoration of a coalmine overburden dump-a case study. Coal International 244,80-83.

Singh, R.S., Tripathi, N., Chaulya, S.K. (2012). Ecological study of revegetated coal mine spoil of an Indian dry tropical ecosystem along an age gradient. Biodegradation 23,837-849.

Singh, R.S., Singh, R.K., Bera, S. (2017). Impact of mining on herbaceous ground cover and wildfauna in BirshaDamoh forest range of Malanjkhand copper mines of India.. Eurasian Journal of Forest Science. 5(1), 1-7

Siti Najilaa, M.J., Noor, R.A., Mohamad Kamelb, A.G., Syed Zahirb, S.I., Khozirahd, S., Lokman, H.S., Zakiaha, I., Azizold, A.K. (2002). The screening of extracts from Goniothalamus scortechinii, Aralidium pinnatifidum and Andrographis paniculata for anti-malarial activity using the lactate dehydrogenase assay. J. Ethnopharmacol. $82,239-242$.

Solanki, R. (2010). Some medicinal plants with antibacterial activity. Int. J. Comp. Pharm. 1(4),1-4.

Somani, R., Kasture, S., Singhai, A.K. (2006). Antidiabetic potential of Butea monosperma in rats. Fitoterapia 77,86-90.

Sriram, S., Meenaa, V., Kavitha, S.J. (2012). Evaluation of antibacterial activity of Chlorophytum borivilianum against selected pathogens. Journal of Research in Antimicrobials 1, 028-031.

Stintzing, F.C., Carle, R. (2005). Cactus stems (Opuntia spp.): A review on their chemistry, technology and uses. Mol. Nutr. Food Res. 49,175-194.

Stintzing, F.C., Schieber, A. (2001). Carle R. Phytochemical and nutritional significance of cactus pear. Eur. Food Res. Technol. 212,396-407.

Sundaram, M.S., Mahadevappa, H., Martin, S., Santhosh, M.P., Kabburahalli, S., Thushara, R.M., Somanathapura, K., Naveen, K., Shivanna, N., Sannaningaiah, D., Kanchugarakoppal, S.R., Kempaiah, K., Kesturu, S.G. (2015). Tamarind Seed (Tamarindus indica) Extract Ameliorates Adjuvant-Induced Arthritis via Regulating the Mediators of Cartilage/Bone Degeneration, Inflammation and Oxidative Stress. Sci. Rep. 5,111-17.

Swati, D.L., Langade, D. Bhattacharyya, Sauvik (2015). Clinical Study Efficacy and Safety of Ashwagandha (Withania somnifera) Root Extract in Improving Sexual Function in Women: A Pilot Study BioMed Research International. 9. DOI: 10.1155/2015/284154

Toledo, V.M. (1995). New paradigms for a new ethnobotany: reflections on the case of Mexico. In: Schultes R.E. and von Reis S. (Eds) Ethnobotany: Evolution of a Discipline. Chapman \& Hall, London 75-88.

Tortoriello, J., Romero, O. (1992). Plants used by Mexican traditional medicine with presumable sedative properties: an ethnobotanical approach. Archives of Medical Research 23,111-116.

Tripathi, N, Singh, R.K. Pal, D., Singh, R.S. (2015). Agroecology and sustainability of agriculture in India: An overview. E-Cronicon: EC Agriculture. 2(1) 241-248. 
Tripathi, N., Singh, R.S., Singh, J.S. (2009). Impact of post-mining subsidence on nitrogen transformation in Southern Tropical Dry Deciduous Forest, India, Environmental Research 109 (3), 258-266.

Tripathi, N., Singh, R.S. (2012). Impact of Savannization on Nitrogen Mineralization in an Indian Tropical Forest. Forest Research 1(3), 1-10, doi:10.4172/2168-9776.1000108.

Tripathi, N., Singh, R.S. (2012). Influence of different land uses on soil nitrogen transformations after conversion from an Indian dry tropical forest. Catena, 77, 216-223.

Tripathi, N., Singh, R.S., Chaulya, S.K. (2012). Dump stability and soil fertility of a coal mine spoil in Indian dry tropical environment: a long-term study. Environmental Management, Springer 50 (4), 695-706.

Tripathi, N., Singh, R.S. (2013). Cultivation impacts soil microbial dynamics in dry tropical forest ecosystem in India. Acta Ecologica Sinica, Elsevier 33, 344-353.

Tripathi, N., Singh, R.S, Nathanail, C.P. ( 2014). Mine spoil acts as a sink of Carbon dioxide in Indian Dry Tropical Environment. Science of the Total Environment, Elsevier 468-469, 1162-1171. (http://www.sciencedirect.com/science/article/pii/S0048969713010620).

Tripathi, N., Singh, R.K, Pal, D. Singh, R.S. (2015). Water Resource Conservation: What Really the Forest Do? J. Journal of Development and Management. 33(3) 6557-6576.

Tripathi, N., Singh, R.S., Hills, C.D. (2016a). Soil carbon development in rejuvenated Indian Coal mine spoil. Ecological Engineering (Elsevier). 90,482-490.

Tripathi, N., Singh, R.S., Hills, C.D. (2016b). Reclamation of Mine Impacted Land for Ecosystem Recovery. 218 Page Wiley Blackwell Publishers, UK. ISBN:9781119057901

Vaghasiya, Y., Chanda, S. (2009). Screening of some traditionally used Indian plants for antibacterial activity against Klebsiella pneumonia. J. Herb. Med. Toxicol. 3,161-4.

Vaidyaratnam, P.S.V. (1994). Indian medicinal plants: a compendium of 500 species, Anna Salai (Madras).Orient Longman 2,52.

Vakil, R.J. (1949). A clinical trial of Rauwolfia serpentina in essential hypertention. Br. Heart J. 11(4), 350.

Valsaraj, R., Pushpangadan, P., et al. (1997). New anti-HIV-1, antimalarial, and antifungal compounds from Terminalia bellerica. J Nat Prod 60,739-742.

Varier, V.P. (1997). Indian Medicinal Plants Compendium of 500 Species. Warrier, P.K., Nambiar, V., Ramankutty, C., eds. Madras, India: Orient Longman 4,58-62.

Verma, S., Singh, S.P., (2008). Current and future status of herbal medicines. Veterinary World 1, 347-350.

Veerapur, V.P., Prabhakar, K.R., Parihar, V.K., Machendar, R.K., Ramakrishna, S., Mishra, B., Satish Rao. B.S., Srinivasan, K.K., Priyadarsini, K.I., Unnikrishnan, M.K. (2009). Ficus racemosa Stem Bark Extract: A Potent Antioxidant and a Probable Natural Radioprotector. Evidence-Based Complementary and Alternative Medicine (eCAM) 6(3),317-324.

Visavadiya, N.P., Narasimhacharya, A.V.R.L. (2011). Ameliorative effects of herbal combinations in hyperlipidemia. Oxidative Medicine and Cellular Longevity. (art. no. 160408)

Wandre, R.A., Bhagwat, G.B., Solunke, R.S., Yadav, M.B., Shaikh, A.M. (2013) A review on medicinal plants with antiulcer activity. J. Pharmacog. Phytochem. 2(1), 235-240.

WHO, (2003). A report by the secretariat on traditional medicine fifty-sixth world health assembly a $56 / 18$ provisional agenda item 14.1031 
Yadava, R.N., Tiwari, L.. (2007). New antifungal flavone glycoside from Butea monosperma O. Kuntze. J. Enzyme Inhib. Med. Chem. 22,497-500.

Yoshinori, A., Reiko, M., Tsumematsu, T. (1982). Mono and sesquiterpenoids from hydrocotyle and Centella species. Phytochemistry 21,2590-2592.

Zorgui, L., Ayed-Boussema, I., Ayed, Y., Bacha, H., Hassen, W. (2009). The antigenotoxic activities of cactus (Opuntia ficus-indica) cladodes against mycotoxin zearalenone in Balb/c mice: Prevention of micronuclei, chromosome aberrations and DNA fragmentation. Food Chem. Toxicol. 47,662-667.

Zou, D.M., Brewer, M., Garcia, F., Feugang, J.M., Wang, J., Zang, R., et al. (2005). Cactus Pear - a natural product in cancer chemoprevention. Nutr. J 4, 25.

Submitted: 23.09.2017; Accepted: 16.10.2017 